Tra quelli inclusi in questo nuovo volume pirandelliano, uno dei saggi più interessanti è indubbiamente quello che studia il rapporto tra la fase giovanile e la successiva produzione letteraria e, soprattutto, teatrale, studio reso possibile e legittimato dalla recente ripubblicazione in veste più organizzata e relativamente più estesa dell'epistolario sia quello curato da Providenti che quello relativo alle lettere a Marta Abba. E dunque oggi possibile approfondire lo studio del giovane Pirandello e documentare così come e quanto rilevanti fossero dall'inizio nella formazione e nell'opera dell'agrigentino centri tematici quali l'arte, la vita e il teatro (68-69). "Pirandello appare quindi, per così dire fin dall'inizio, siciliano, nazionale ed europeo e, insieme, poeta, narratore e drammaturgo"; da questa considerazione Caputo riesce poi a spingersi sino a valutare ora, sì, davvero appieno, anche quella "rivoluzione" di cui tanto si è parlato a proposito di Pirandello, una rivoluzione che spinge le sue propaggini sino all'interno dell' "attuale 'postmoderna' contemporaneità" (69).

Fra gli altri, vorrei in chiusura segnalare anche lo studio dell'umorismo nel pensiero estetico del primo Novecento poiché qui Rino Caputo traccia la mappa da un lato di una più nota sinergia tra Pirandello e il romanticismo tedesco e dall'altro di quella tra Pirandello e Baudelaire. Ammicco e sorrido all'amico-collega poiché anch'io, a suo tempo, avevo delineato la possibilità di uno studio comparato tra l'umorismo pirandelliano e il comico assoluto baudelairiano in un mio piccolo saggio del 1992. Negli ultimi tre saggi del volume Caputo da un lato offre uno studio dettagliato e sottile del grande romanzo storico di Luigi Pirandello, I vecchi e $i$ giovani, seguito poi da un'indagine puntuale del grande romanzo di Tomasi di Lampedusa, $I$ gattopardo, nel quale Caputo ravvede una notevole sintonia con le posizione espresse da Pirandello, ma anche da De Roberto e Verga, nei confronti del Risorgimento. Il volume si chiude con uno studio della letteratura nel romanzo Suo marito che viene qui visto come "snodo poietico, intriso di passato e futuro" (236) e cioè un testo narrativo che sta al centro dello sviluppo compositivo dei romanzi pirandelliani.

Questo nuovo, originale ed avvincente tentativo di ripercorrere le ragioni di poetica e di poiesi dell'autore siciliano si conclude ricordando al suo lettore un'importante ammissione fatta da Pirandello nel 1924, e cioè all'apice della sua fortuna teatrale, "Cerco una cosa sola: esprimere ciò che sento. [...] Sento, perché penso. Penso, perché sento" (252), un'affermazione con la quale si ribadisce la circolarità tra la mente e il corpo dell'opera pirandelliana, e dunque la fondamentale continuità, sempre ribadita nel testo di Caputo, tra inizio e fine del percorso pirandelliano che, secondo lo studioso, nella sua spinta rivoluzionaria, dalla fine dell'Ottocento si spinge sino alla nostra contemporanea postmodernità.

\title{
MANUELA GIERI
}

University of Toronto

Thomas Erling Peterson. Alberto Moravia. New York: Twayne Publishers, 1996. Pp. xii, 170.

The preparation of a critical biography presents a number of challenges with respect to crucial decisions that must be made in terms of what is to be sacrificed and what is to 
be emphasized. In other words, what needs to be determined at the outset is the most desirable or appropriate relationship among the biographical data, explication of the major and minor publications of the author under discussion, the historical and literary context(s) out of which an individual work or a series of works emerge, as well as the correct balance between synopsis and critical commentary. It is often the case that an overemphasis of the biographical axis results in something of a less than profound or 'scientific' treatment of the essential aesthetic or ideological properties of a given body of writing. It can also occur that in the author's ambition to be comprehensive, the monographic study consists largely of a loosely-knit fabric of plot summaries and character sketches which do not rise to the level of establishing a compelling and coherent critical line of development. Thomas Peterson definitely meets the challenges in what is arguably the finest English-language 'introduction' to the life and thought of Alberto Moravia. He skilfully and unobtrusively amalgamates all of the pertinent elements required in an 'overview' or presentation of the work of a writer; all the while he maintains a sharp focus on the evolution of the stylistic, ideological and critical profile of one of Italy's foremost twentieth-century novelists and intellectuals. For Peterson, biographical and historical facts serve primarily an explicative function, accounting as they do for the persistence of a clearly-defined subject matter in the fiction of Moravia. Moravia's essays are also analyzed selectively with a view to correlating the theoretical positions with the structure, themes and tone of the narrative.

Although the overall design of Alberto Moravia is a chronological presentation of a life and a career, Peterson organizes his material in terms of several distinct phases in the emergence or maturation of Moravia as a literary figure, from the late 1920 s to the year of his death, 1990. These phases which he entitles, "The Time of Indifference," "A Cultural Resistance to Fascism," "Tales of Adolescence," "The NationalPopular Myth." "The Road to Metafiction and Back," and "The Protean Faces of the Master," mark well-defined stages in the articulation of Moravia's narrative voice. Such a design comes out of what many critics of Moravia take to be a defect or limitation in the artist's imagination, namely, the fact that "Moravia displays a constant concern for the same themes: love and sexuality, and money and material survival" (3), particularly as applied to the Italian middle class. However, early in his study, Peterson makes it perfectly clear that he intends to demonstrate the positive, indeed original, aspects of this type of consistency. He writes: "Moravia's sincerity, and therefore his extremism, was to be found in his insistence on a few select themes, startling in their modernity, and in the artisanal care with which he developed them adhering to a narrative craft that owed much to the novels of the $19^{\text {th }}$ century" (18). As is amply illustrated, this same allegiance to a narrow range of themes and to a more or less traditional method of storytelling does not preclude Moravia from composing postmodern metafiction or from critiquing that form of writing.

The progression from the realism of the first novel, Gli indifferenti, to the metafiction of Il disprezzo, La noia and L'attenzione is the text's organizing principle and Peterson is meticulous in arguing and referencing the distinctiveness of each phase as well as the intertextuality, (what Peterson calls 'thematic continuity') that constantly refers the reader back to previous narratives or or causes the reader to anticipate later developments. To this end, he provides beautifully-crafted synopses of major novels and key novellas, but he is always alert to isolate only those primary narrative seg- 
ments that are germane to the thesis. Biographical details are kept to a minimum and they too are selected because of their import with respect to the presence of certain modalities or a specific thematic line in the narrative works of a given period. The same can be said for the historical realities, whether they be those that pertain to Moravia's experiences under Fascism, during the post-war economic recovery or in the consumer society of the1970s and 1980s. Underpinning Peterson's thought are the following presuppositions about the entire body of work: the determination to preserve the "autonomy of the artist" (1), the "moral imperative at the base of his work" (1) and the "abstract striving toward an intellectual ideal" (19). Peterson argues persuasively the verifiability of these criteria in each of the sections or stages of the evolution of Moravia's writing.

What is equally impressive about this monograph is the manner in which Peterson engages the major Moravia critics. He frequently acknowledges the substantial contribution of prominent figures such as Debenedetti, Pedullà, Siciliano, Pampaloni, David, Fontanella and Muscetta, but he is also capable of pointing out lacunae in critical attention. For example, he has this to say about Le ambizioni sbagliate: "The lack of commentary on such a major novel upset the author and remains to this day a gap in Moravia criticism" (30). Peterson can also adroitly rein in wayward interpretations, as when he writes: "One realizes the critic (Muscetta) has lost sight of the text. It is precisely the act of being scandalized [...] that Moravia calls conformism" (69). On a larger scale, he takes issue with the opinions expressed by Moravia critics in general. We can take as exemplary the following statement: "It is a cliché among critics that after 1960 Moravia turned to a more intellectualist fiction, dependent more on the pretense of a story and the repetitive internal mechanisms of his protagonists than the verisimilitude or drama of their actions. [...] Such critics see the changes as the beginning of a decline which at its nadir lapses into sensationalist self-imitation" (87). He then goes on to say that such a perspective "overlooks the vigor of Moravia's intellectual posture of the 1960 s and beyond" (87).

Peterson's dialogue with Moravia's many texts and their critics converge on the nature of Moravian realism as it presents itself at various stages of the writer's career. Peterson analyzes the aesthetic of this realism, drawing on interpretative discourses (his and that of noted critics) as well as on the novelist's own views, as expressed in his essays, especially those of the collection L'uomo come fine, and defines that realism against the backdrop of Verghian naturalism in the first instance, of neorealism subsequently and eventually of experimentalism of the nouveau roman and post-modernist fiction in general. His most significant contribution is the argumentation in favour of a set of aesthetic and moral principles which Peterson paradoxically calls "conscientious realism" (20) or "utopian realism" (19). In other words, Peterson argues that beneath the 'critical realism' which most critics agree is the hallmark of Moravian prose, the reader can detect the constant presence of an optimism or a "utopian desire of the author for a serene reality" (32). Lest we think that the optimism is attributed solely only to the author (implied or real, as the case may be), Peterson is carefull to extend this interpretation to the societies represented in Moravia's works by defining a utopian society as one "in which loves and logic are not antagonistic" (20).

Although a study of this kind necessarily entails the sacrifice of a certain degree of depth in that no one specific text or critical methodology can be fully exploited, the 
scope and intelligence of Thomas Peterson's enterprise makes of Alberlo Moravia an indispensable addition to Moravia criticism.

\section{CORRADO FEDERICI}

Brock University

Cristina Della Coletta. Plotting the Past. Metamorphoses of Historical Narrative in Modern Italian Fiction. Indiana: Purdue University Press, 1996. Pp. 268.

Nietzsche once wrote that " $[t]$ he measurement of the opinions and deeds of the past by the universal opinions of the present is called "objectivity" (The Use and Abuse of Hislory 44). He subsequently alters this assumption by suggesting that an objective plotting of history is naive since the narrative rendering of past events is by necessity mediated through the present act of interpretative organization, itself a highly subjective (and therefore, literary) strategy that "requires above all a great artistic faculty" (46). For Nietzsche, therefore, historical writing is not objective but is essentially a literary enterprise involving a subjective reconfiguration of the past by means of the discursive practices of the present which have an organizing function as that which imposes sense on contingent past events. In Nietzsche's definition of history writing: "its real value lies in inventing ingenious variations on a probably commonplace theme, in raising the popular melody to a universal symbol and showing what a world of depth, power and beauty exists in it" (46).

In exposing the aesthetic and relative nature of historical narrative and the fictional status of epistemological objectivity (which Nietzsche calls a "pious illusion") Nietzsche aligns himself with contemporary postmodern poetics which classify all textual documentation of the past as subjective discourses, the epistemological foundations of which are determined by the literary principle of "emplotment" (Plotting 60). That is, only by artificially organizing the temporal events comprising experience within the contained framework offered by a narrative plot do the incidents of the past become ordered, acquire continuity and are, therefore, intelligible to the human mind.

In Plotting the Past Cristina Della Coletta recalls Nietzsche's dictum by itemizing novels that self-consciously explore and expose the subjective nature of the literary "emplotment" of the past. The author shows that the self-legitimating powers of alternative fiction-making thematized in postmodern historical novels ("critical historical novel") question and subvert standard historical factuality and reveal the essentially provisionary and highly subjective status of all knowledge and historical discourse. The fact that all forms of acquired knowledge originate from textuality and are organized by the subjectivity of the author suggests that the act of writing itself offers alternative forms of knowledge which may be seen as subverting and challenging normative historical truths and exposing the latter as fictional constructs.

In concert with other theorists (Hutcheon, Eco, Jameson) Della Coletta contends that the postmodern revival of historical fiction writing is underpinned by a self-aware critical revisiting of the historical novel's ontological and epistemological relation 